\title{
KAJIAN PENGARUH BERAT BIJI KAKAO PERKOTAK DAN WAKTU PENGADUKAN TERHADAP KEBERHASILAN PROSES FERMENTASI
}

\author{
St. Sabahannur ${ }^{1}$, Nirwana ${ }^{1}$ \\ ${ }^{1}$ Fakultas Pertanian Universitas Muslim Indonesia \\ Jl. Urip Sumoharjo KM 5, Makassar \\ E-mail: siti_sabahan@yahoo.com
}

\begin{abstract}
This study aim to influence seed weight per box of fermentation and stirring time on the success of the fermentation process. Research using a randomized block design with two factors. The first factor seed weight per box consists of: $15 \mathrm{~kg}, 20 \mathrm{~kg}$ and $25 \mathrm{~kg}$. The second factor, while stirring during fermentation: stirring during 48 hours (1 time), and a stirring time of 48, 72, and 96 hours (3 times) fermentation. The results showed fermentation of cocoa beans each $15 \mathrm{~kg}, 20 \mathrm{~kg}$ and $25 \mathrm{~kg}$ has no effect on changes in temperature, $\mathrm{pH}$, total acid and fermentation index. The highest temperature during fermentation at $44-45^{\circ} \mathrm{C}$, while stirring time (aeration) significantly affects the $\mathrm{pH}$, fermentation index and slaty beans. Stirring 3 times better than one times in terms of $p H$ (5.6), fermentation index of 1.62 and $3.4 \%$ slaty beans.
\end{abstract}

Keywords: fermentation, seed weight, stirring, index fermentation

Indonesia memiliki luas areal kakao saat ini sudah mencapai 1,7 juta hektar (ha), dimana 1 juta ha terdapat di Pulau Sulawesi. Produksi kakao di Sulawesi rata-rata mencapai 145.000 ton per tahun sehingga dapat memberikan kontribusi secara nasional sebesar 60\% (Amalia, 2014)

Perkebunan kakao rakyat merupakan faktor kunci ketersedian dan keberlanjutan bahan baku untuk industri olahan kakao. Dari 720.862 ton produksi kakao Indonesia $92 \%$ dihasilkan dari perkebunan rakyat. Jumlah tersebut dihasilkan dari areal seluas 1.740 .612 ha, dimana $95 \%$ nya merupakan perkebunan rakyat, sisanya perkebunan besar nasional dan perkebunan besar swasta (Isra, 2016).

Sampai saat ini, kurang lebih 90\% petani menjual kakao dalam bentuk biji untuk diekspor, namun mutunya rendah karena tidak difermentasi, kadar air masih tinggi, ukuran biji tidak seragam, kadar kulit tinggi, keasaman tinggi, cita rasa sangat beragam dan tidak konsisten. Selain itu terdapat biji kakao yang terserang/infestasi serangga hama, terserang jamur, dan tercampur dengan kotoran atau benda-benda asing lainnya.

Sulawesi Selatan mengekspor kakao terutama dalam bentuk biji yang tidak terfermentasi. Hal ini disebabkan karena kurangnya 
kesadaran petani maupun pedagang kakao untuk melakukan fermentasi biji kakao. Akibatnya mutu kakao selalu dinilai buruk (grade $\mathrm{C}$ ). Biji kakao kering yang dihasilkan petani di Indonesia secara keseluruhan masih dikelola secara tradisional. Permasalahan pengolahan kakao ditingkat petani adalah kurangnya pengetahuan terhadap teknologi pengolahan biji kakao dan belum adanya satu prosedur baku guna menghasilkan biji kakao kering yang berkualitas. Hal inilah yang agak mempersulit dalam pengendalian mutu biji kakao. Petani memproduksi biji kakao kering dengan mutu yang masih rendah, seperti keasaman tinggi, flavornya pahit dan sepat, kadar biji slaty (biji kakao yang tidak terfermentasi), kotoran dan biji berkecambah masih tinggi, adanya kontaminasi serangga, jamur dan mitotoksin, adanya bau abnormal serta ukuran biji yang tidak seragam sehingga menyebabkan biji kakao yang dihasilkan belum memenuhi standar SNI biji kakao (Kementerian Pertanian, 2012)

Berdasarkan

Peraturan

Kementrian Pertanian (Permentan) Nomor 67 Tahun 2014 tentang Persyaratan Mutu dan Pemasaran biji kakao, disebutkan bahwa seluruh petani kakao wajib mengimplementasikan kakao fermentasi untuk memenuhi Standar Nasional Indonesia (SNI) 2323:2008/2010 (Sinartani, 2016)

Sampai saat ini, petani kurang memiliki keinginan untuk melakukan fermentasi terhadap biji kakaonya. Hal ini disebabkan selisih harga penjualan antara kakao yang sudah difermentasi dan yang tidak difermentasi hanya berkisar antara
2000-2900 Rupiah per kg. Selain itu, petani harus menunggu 3-5 hari jika melakukan fermentasi.

Produktivitas yang masih rendah juga menjadi penyebab enggannya petani melakukan fermentasi. Selain itu tidak tersedianya sarana pengolahan yang memadai, karena petani beranggapan untuk melakukan fermentasi harus dalam jumlah besar, minimal berat biji kakao $50 \mathrm{~kg}$ per kotak, sehingga petani yang memiliki buah kakao dalam jumlah kecil tidak mampu melakukan fermentasi.

Kesempurnaan proses fermentasi antara lain dipengaruhi oleh berat minimal biji, pengadukan (pembalikan), lama fermentasi, dan bentuk kotak fermentasi (Iflah dan Towaha, 2015). Berat biji basah minimum (critical mass) merupakan salah satu persyaratan yang harus dipenuhi agar diperoleh suhu yang ideal untuk berlangsungnya proses fermentasi yang baik (Widyotomo \& Sri-Mulato, 2008). Proses fermentasi di dalam peti dengan rasio luas permukaan dan volume fermentasi yang kecil akan menghasilkan suhu fermentasi $45^{\circ} \mathrm{C}$ walaupun jumlah biji basahnya hanya $20 \mathrm{~kg}$. Menurut SriMulato et al (1995), berat biji basah jenis kakao Lindak untuk proses fermentasi sebaiknya tidak kurang dari $40 \mathrm{~kg}$ dan ketebalan pemeraman $40 \mathrm{~cm}$. Hal ini terkait dengan kemampuan untuk menghasilkan panas yan cukup agar proses fermentasi berjalan dengan baik. Jadi, semakin banyak biji yang difermentasi, maka potensi produksi panas juga semakin besar (Mursyid, 2012).

Menurut Setiavani (2009), fermentasi dengan kotak/peti yang 
berukuran panjang $60 \mathrm{~cm}$ dengan tinggi $40 \mathrm{~cm}$ (kotak dapat menampung $\pm 100 \mathrm{~kg}$ biji kakao basah) setelah itu kotak ditutup dengan karung goni/daun pisang. Pada hari ke 3 (setelah 48 jam) dilakukan pembalikan agar fermentasi biji merata. Pada hari ke 6 biji-biji kakao dikeluarkan dari kotak fermentasi dan siap untuk dijemur Kotak fermentasi yang terlalu dalam akan menyebabkan proses fermentasi hanya terjadi pada bagian tengah saja. Biji dibalikkan setiap 48 jam selama fermentasi berlangsung.

Tujuan pengadukan pada massa biji kakao selama fermentasi adalah untuk menjamin keseragaman. Adanya perbedaan antar bagian massa biji kakao yang difermentasi menyebabkan pentingnya pengadukan selama berlangsungnya proses fermentasi. Dalam kotak fermentasi, biji basah biasanya menggumpal selama hari pertama, sementara itu 'cairan pulp' mengalir keluar. Pengadukan dibutuhkan untuk mempermudah udara masuk kedalam tumpukan biji. Terdapat beberapa variasi pada frekuensi pengadukan, yakni mulai dari tanpa pengadukan sama sekali hingga pengadukan dua kali sehari pada fermentasi dalam silinder. Hal ini telah diuji-coba di Kamerun dan Pantai gading (Ivory Coast).

Berdasarkan hal tersebut maka dilakukan penelitian mengenai fermentasi biji kakao skala kecil dengan melakukan pembalikan setiap 24 jam. Tujuan penelitian adalah mengkaji pengaruh berat biji per kotak dan waktu pengadukan terhadap perubahan suhu, $\mathrm{pH}$, total asam dan indeks fermentasi biji kakao.

\section{METODE}

Bahan-bahan penelitian meliputi buah kakao, kotak fermentasi dengan kapasitas masing-masing $15 \mathrm{~kg}, 20 \mathrm{~kg}$ dan $25 \mathrm{~kg}$, bahan kimia untuk analisis meliputi: $\mathrm{NaOH} 0,1 \mathrm{~N}$, metanol $90 \%$, $\mathrm{HCl}$ pekat, kertas $\mathrm{pH}$, dan aquades. Alat yang digunakan adalah balok kayu pemecah buah kakao, pH-meter, termometer, timbangan analitik, gelas ukur, blender, spektofotometer tipe UV-Vis, dan oven (Memmert).

Rancangan penelitian: percobaan menggunakan Rancangan Acak Kelompok (RAK) pola faktorial dua faktor. Faktor pertama adalah berat biji per kotak fermentasi (F) yang terdiri dari $15 \mathrm{~kg}(\mathrm{~F} 1), 20 \mathrm{~kg}(\mathrm{~F} 2)$, dan $25 \mathrm{~kg}$ (F3). Faktor kedua, waktu pengadukan selama proses fermentasi (P) terdiri dari dua cara yaitu pengadukan pada saat 48 jam fermentasi (P1), dan pengadukan saat 48 jam, dilanjutkan pengadukan pada saat 72 jam, dan 96 jam (P2).

Tahap-tahap pelaksanaan penelitian:

a. Buah kakao dipecah dengan menggunakan balok kayu, kemudian biji dikeluarkan, dan dilepas dari plasenta

b. Kotak fermentasi yang digunakan dilubangi pada dasar dan keempat dindingnya, tujuannya agar supaya cairan pulp mudah keluar dari kotak fermentasi. Ukuran lubang berdiameter $1 \mathrm{~cm}$ dan jarak antara lubang 5-10 cm, kemudian kotak diberi alas dari daun pisang,

c. Biji dimasukkan ke dalam kotak dengan berat masing-masing 15 $\mathrm{kg}, 20 \mathrm{~kg}$ dan $25 \mathrm{~kg}$ (sesuai perlakuan), selanjutnya kotak ditutup dengan daun pisang dan karung goni. 
Kajian Pengaruh Berat Biji Kakao 21

d. Pembalikan dilakukan pada saat fermentasi berlangsung 48 jam, dengan cara memindahkan biji kakao ke kotak yang baru.

e. Pengadukan dilakukan lagi pada saat fermentasi berlangsung 72 jam, dan 96 jam atau setiap hari setelah pembalikan. Fermentasi berlangsung selama lima hari (120 jam)

f. Biji kakao yang sudah difermentasi dijemur di bawah sinar matahari selama 4 hari atau kira-kira kadar air sudah mencapai 6-7\% .

Parameter pengamatan:

\section{- Suhu fermentasi kakao}

Pengukuran suhu fermentasi dilakukan dengan menggunakan termometer pada tumpukan biji kakao selama fermentasi (setiap 24 jam) pada 7 titik yang berbeda yaitu di bagian atas, 3 titik di bagian tengah, dan 3 titik di bagian bawah.

- Tingkat Keasaman (pH) biji kakao basah

Pengukuran pH luar/ permukaan biji dilakukan dengan cara mengambil \pm 15 g biji basah dari tiap titik yang berbeda, dihomogenkan, kemudian dilarutkan dalam $15 \mathrm{ml}$ aquades lalu diukur $\mathrm{pH}$. Pengukuran $\mathrm{pH}$ dalam/keping biji dilakukan dengan cara mengambil \pm 5 g keping biji yang telah dihaluskan, kemudian dilarutkan dalam $10 \mathrm{ml}$ aquades lalu diukur $\mathrm{pH}$. Pengukuran $\mathrm{pH}$ dilakukan sebanyak 2 kali.

- Total asam titrasi

(TAT)

(Sudarmadji, et al., 1997).

Cara pelaksanaan

a. $10 \mathrm{ml}$ suspensi ditambah tiga tetes indikator fenolftalein, kemudian dititrasi dengan larutan $\mathrm{NaOH}$ $0,1 \mathrm{~N}$. b. Pengujian dilakukan sebanyak 5 kali ulangan. Total asam tertitrasi dihitung berdasarkan rumus:

$\% T A T=m l N a O H \times N N a O H x f P \times 100$ Beratsampel $(g)$

\section{pH keping biji kering (BSN: SNI 2323:2008).}

Prosedur pelaksanaan

a. Diambil contoh uji sebanyak 12 biji sampai dengan 20 biji, dipisahkan kulit luarnya dan kemudian digiling dengan menggunakan blender

b. Ditimbang contoh uji tersebut sebanyak $\pm 10 \mathrm{~g}$ ke dalam gelas piala, tambahkan $90 \mathrm{ml}$ air suling panas $\left(70^{\circ} \mathrm{C}\right.$ sampai dengan $\quad 80^{\circ} \mathrm{C}$ ), diaduk perlahan-lahan sampai terbentuk suspensi yang harus bebas dari gumpalangumpalan

c. Disaring dan didinginkan filtratnya sampai suhu kamar $(27 \pm 2)^{\circ} \mathrm{C}$ dan ditentukan $\mathrm{pH}$ filtrat secepat mungkin pada suhu tersebut. Hasil dinyatakan sesuai dengan pembacaan yang ditunjukkan oleh $\mathrm{pH}$-meter untuk filtrat tersebut.

- Indeks Fermentasi (Metode Gourieva dan Tserevitinov, 1979 Misnawi, et al, 2003)

Prosedur pelaksanaan

a. Keping biji kakao yang telah dihaluskan (bubuk kakao) sampai 40 mesh ditimbang sebanyak $0,5 \mathrm{~g}$ kemudian diekstrak dengan campuran methanol dan $\mathrm{HCl}$ pekat dengan perbandingan $97: 3$ sebanyak $50 \mathrm{ml}$. Ekstrak biji 
kakao dihomogenkan selama 20 detik menggunakan homogenizer, setelah itu disimpan selama 20 jam pada suhu $8^{\circ} \mathrm{C}$. Ekstrak diukur absorbansinyamenggunakan spektonik pada panjang gelombang $460 \mathrm{~nm}$ dan 530 nm. Nilai indeks fermentasi (IF) ditentukan dengan rumus:

$$
I F=\frac{a b s \lambda 460 \mathrm{~nm}}{a b s \lambda 530 \mathrm{~nm}}
$$

- Biji slaty dengan metode uji belah (cut test) (Senanayake et al. dalam Kustyawati \& Sri Setyani, 2008; SNI 2323-2008).

\section{Prosedur pelaksanaan}

a. Penentuan derajat fermentasi berdasarkan warna keping biji dilakukan dengan membelah biji kakao (uji belah/cut test) dengan arah melintang sehingga permukaan biji yang terbelah dapat dilihat dengan jelas (Misnawi, 2005).

b. Cut test dilakukan untuk mengetahui tingkat fermentasi biji kakao yang dikelompokkan berdasarkan warna permukaan keping biji kakao yang telah dibelah. Prosedur pengujian biji kakao dimulai dengan menyiapkan contoh uji sebanyak 300 biji yang diambil secara acak. Kemudian dibelah memanjang dengan pisau tajam untuk menampakkan seluruh permukaan kotiledon. Warna kedua belahan biji diamati secara visual dalam cahaya matahari (daylight), mengamati satu persatu adanya biji fermentasi, biji tidak terfermentasi, dan biji ungu yang tampak. Khusus dalam penentuan biji slaty, apabila terdapat keraguan terhadap warna, sebaiknya keping biji tersebut digigit dan dicicipi, rasa pahit dan sepat yang ditimbulkan menandakan bahwa biji slaty.

Kelompok warna permukaan keping biji kakao terdiri dari: biji brown (coklat) adalah biji yang memperlihatkan $3 / 4$ atau lebih permukaan irisan keping biji berwarna coklat dan umumnya berongga, biji brown/purple (ungu) adalah biji brown yang memperlihatkan $1 / 2$ dari permukaan keping biji berwarna ungu, biji purple (ungu) adalah biji yang memperlihatkan $3 / 4$ dari permukaan biji berwarna ungu, dan biji slaty (keabu-abuan) adalah biji yang tidak terfermentasi pada kakao Lindak yang memperlihatkan l/2atau lebih permukaan keping biji berwarna keabu-abuan atau biru keabu-abuan, umumnya bertesktur padat dan pejal seperti keju. Jumlah biji slaty dihitung dengan rumus

$$
X=\frac{M 1}{M 0} \times 100 \%
$$

Keterangan : $\mathrm{X}$ : biji slaty

M0: jumlah contoh uji (300 biji kakao) M1: jumlah biji slaty

\section{HASIL DAN PEMBAHASAN Suhu}

Pengaruh berat biji per kotak dan waktu pengadukan selama fermentasi tidak berpengaruh nyata terhadap suhu selama fermentasi biji kakao. Rata-rata suhu harian selama proses fermentasi disajikan pada Gambar 1. 


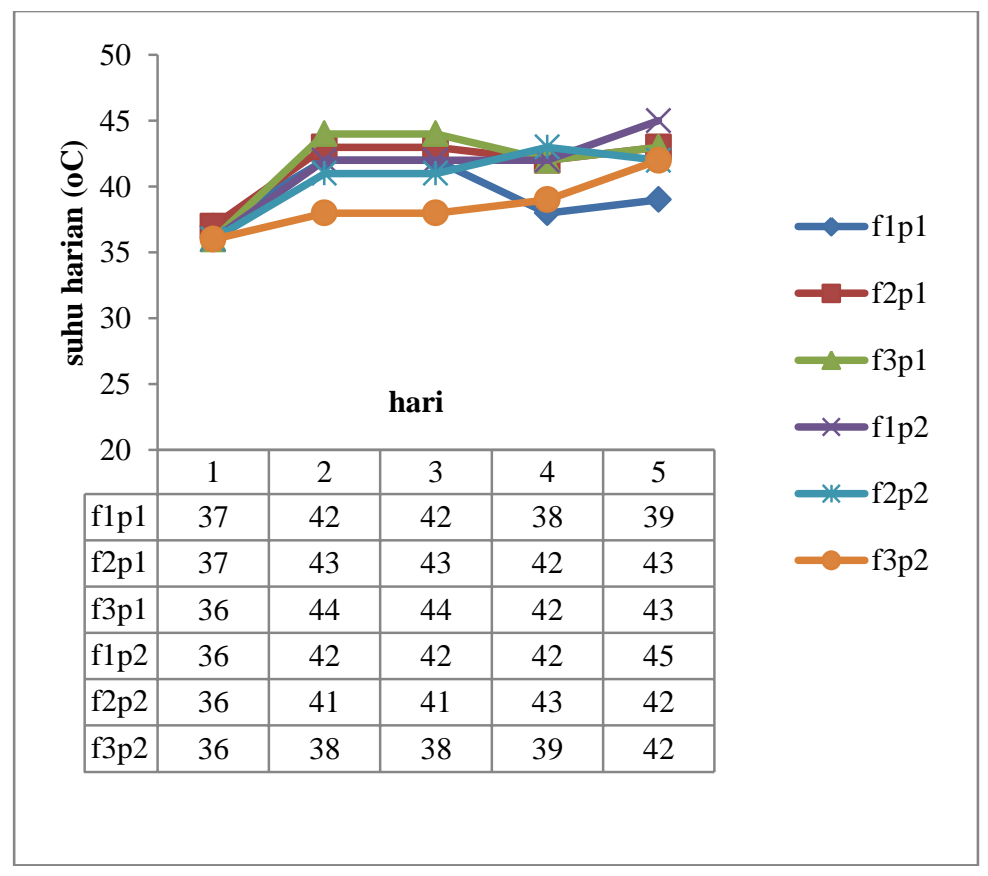

Gambar 1.Rata-rata suhu harian selama 5 hari fermentasi

Gambar 1 menunjukkan bahwa suhu fermentasi tidak mengalami perubahan yang signifikan setelah dilakukan pembalikan (pengadukan) pada saat 48 jam, 72 jam maupun 96 jam baik pada berat biji $15 \mathrm{~kg}, 20 \mathrm{~kg}$ maupun $25 \mathrm{~kg}$ biji per kotak.

Suhu $45^{\circ} \mathrm{C}$ merupakan suhu tertinggi dicapai pada hari ke lima pada volume biji kakao $15 \mathrm{~kg} / \mathrm{kotak}$ dengan waktu pengadukan 48 jam, 72 jam dan 96 jam (3 kali pembalikan). Suhu yang dicapai selama berlangsungnya proses fermentasi antara $39-42^{\circ} \mathrm{C}$.

pH

Pengaruh berat biji perkotak fermentasi dan interaksinya dengan waktu pengadukan tidak berpengaruh nyata, sedangkan waktu pengadukan berpengaruh nyata terhadap $\mathrm{pH}$ biji kakao. Rata-rata $\mathrm{pH}$ biji diperlihatkan pada Tabel 1.

Tabel 1. pH biji kakao setelah fermentasi

\begin{tabular}{ccccc}
\hline \multirow{2}{*}{ Pengadukan } & \multicolumn{3}{c}{ Berat biji per kotak } & \multirow{2}{*}{ Rataan } \\
\cline { 2 - 4 } & $\mathbf{1 5}$ & $\mathbf{2 0}$ & $\mathbf{2 5}$ & \\
\hline 1 kali & 4,8 & 4,9 & 4,9 & $4,9 \mathrm{a}$ \\
3 kali & 5,7 & 5,9 & 5,3 & $5,6 \mathrm{~b}$ \\
\hline Rataan & 5,2 & 5,4 & 5,1 & \\
\hline
\end{tabular}

Keterangan: Angka yang diikuti huruf yang berbeda (a,b), berbeda nyata pada uji BNT 0,05 
Berdasarkan uji BNT taraf 0,05 bahwa,pengadukan yang dilakukan hanya satu kali (48 jam) berbeda nyata dengan pengadukan yang dilakukan tiga kali (48 jam, 72 jam, dan 96 jam fermentasi). $\mathrm{pH}$ biji kakao padapengadukan sebanyak tiga kali mempunyai $\mathrm{pH}$ lebih tinggi yaitu 5,6, sedangkan $\mathrm{pH}$ biji kakao pengadukan hanya satu kali $\mathrm{pH}-$ nya 4,9 . Nilai $\mathrm{pH}$ biji kakao yang tinggi untuk waktu pengadukan 48 jam, 72 jam dan 96 jam dikarenakan massa biji kakao mendapat pengadukan lebih banyak sehingga aktivitas bakteri asam asetat berlangsung lebih baik, sehingga proses pembentukan asam asetat lebih mudah terjadi dilingkungan yang memiliki derajat pengadukan lebih besar. Nilai $\mathrm{pH}$ biji kakao yang baik adalah mendekati netral $(\mathrm{pH}>6)$ agar senyawa-senyawa khas cokelat dapat terbentuk secara intensif (Indarti, et al. 2011).

Biji kakao dengan nilai keasaman dinyatakan dalam satuan $\mathrm{pH}$ dengan nilai 5,20-5,50 atau nilai titrasi asam 0,12-0,15 meq/g diterima sebagai biji kakao dengan tingkat keasaman optimal oleh pabrikan cokelat. Biji yang tergolong asam mempunyai $\mathrm{pH}<5,0$ (Sulistyowati, 1988). Menurut Lopez \& Passos (1984), pabrikan di Eropa dan Amerika menghendaki biji kakao kering dengan $\mathrm{pH}$ pada kisaran 5,15,8, pH 5,2 paling disukai (Soetiadjo \& Mangoensoekarjo, 1980). $\mathrm{pH}$ kakao tidak boleh kurang dari 3,5. Industri pengolah kakao menghendaki $\mathrm{pH}$ biji antara 5,2-5,8 untuk menghasilkan cocoa butter yang berkualitas (Wood \& Lass, 2001, Widianto, et al., 2013).

\section{Total Asam}

Hasil pengukuran total asam tertitrasi pada biji kakao pada perlakuan berat biji per kotak dan waktu pengadukan tidak berpengaruh nyata. Hubungan antara waktu pengadukan dengan total asam disajikan pada Gambar 2.

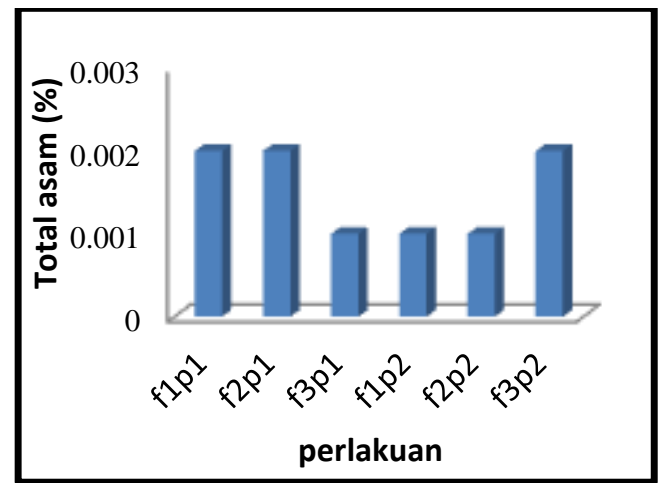

Gambar 2. Total asam biji kakao

Pada Gambar 2 menunjukkan, kadar total asam biji kakao mempunyai kisaran nilai 0,001$0,002 \%$. Nilai total asam yang diperoleh masuk kategori rendah. Hal ini sejalan dengan nilai $\mathrm{pH}$ biji kakao yang mendekati netral (Tabel 1).

Asam dalam biji kakao termasuk dalam asam-asam organik yang terbagi dalam kelompok asam organik mudah menguap (terutama asam asetat) dan asam organik yang tidak mudah menguap (asam laktat, suksinik, malat, oksalat, dan tartarat). Asam asetat merupakan komponen asam dengan konsentrasi paling besar mencapai $788 \mu \mathrm{g} / \mathrm{g}$ (Wahyudi dkk., 2013). Asam-asam organik yang terbentuk seperti asam laktat dan asam asetat. Asam-asam tersebut akan berpengaruh terhadap keasaman $(\mathrm{pH})$ biji setelah fermentasi (Ardhana \& Fleet, 2003; Ramlah \& Daud, 2009; Guehi, et al., 2010; Pasau, 2013). 
Diantara atribut-atribut rasa cokelat, rasa asam merupakan atribut penting yang juga memberikan kontribusi yang nyata terhadap citarasa keseluruhan produk cokelat (Jinap et al. 1994). Kehadiran rasa asam dalam jumlah sedikit akan menyumbang pada keseimbangan citarasa cokelat tetapi pada jumlah yang lebih besar, rasa asam diterima sebagai cacat rasa.

\section{Indeks Fermentasi}

Hasil pengukuran indeks fermentasi biji kakao dipengaruhi oleh waktu pengadukan (pengadukan) sedangkan berat biji perkotak dan interaksinya tidak berpengaruh nyata. Rata-rata indeks fermentasi biji kakao disajikan pada Tabel 2.

Tabel 2. Indeks fermentasi biji kakao

\begin{tabular}{ccccc}
\hline \multirow{2}{*}{ Pengadukan } & \multicolumn{3}{c}{ Berat biji per kotak } & Rata- \\
\cline { 2 - 4 } & $\mathbf{1 5}$ & $\mathbf{2 0}$ & $\mathbf{2 5}$ & rata \\
\hline 1 kali & 1,62 & 1,58 & 1,46 & $1,55 \mathrm{a}$ \\
3 kali & 1,63 & 1,59 & 1,62 & $1,61 \mathrm{~b}$ \\
\hline Rata-rata & 1,62 & 1,58 & 1,54 & \\
\hline
\end{tabular}

Keterangan: Angka yang diikuti huruf yang berbeda (a, b) berarti berbeda nyata pada uji BNT 0,05.

Tabel 2 menunjukkan, waktu pengadukan 3 kali (48 jam, 72 jam dan 96 jam) mempunyai nilai indeks fermentasi 1,61 berbeda nyata dengan waktu pengadukan 1 kali ( 48 jam). Walaupun terdapat perbedaan nilai indeks fermentasi tetapi waktu pengadukan berpengaruh nyata terhadap indeks fermentasi di mana masing-masing mempunyai nilai lebih besar dari 1. Fermentasi biji dengan nilai indeks fermentasi (IF) sama dengan satu dandi atas satu dianggap fermentasi sempurna, sedangkan fermentasi biji kakao dengan nilai $I F<1$ menunjukkan fermentasi tidak sempurna (Gourieva \& Tserrevitinov, 1979; Alamsyah, 1991).

Indeks fermentasi merupakan tolok ukur derajat fermentasi secara kimiawi. Hasil pengukuran kimiawi ini lebih objektif dibandingkan dengan hasil uji belah (cut test), karena nilainya didasarkan pada tingkat absorbansi senyawa-senyawa hasil fermentasi dan pembentukannya. Senyawa hasil fermentasi adalah tanin kompleks berwarna coklat yang memberikan absorbansi maksimal pada panjang gelombang $460 \mathrm{~nm}$, senyawa yang berkurang selama fermentasi adalah antosianin yang berwarna ungu dengan absorbansi maksimal pada panjang gelombang $530 \mathrm{~nm}$ (Gourieva \& Tserevitinov, 1979)

Indeks fermentasi adalah ukuran kecoklatan dari biji kakao untuk memastikan tingkat fermentasi biji (Takrama, et al., 2006). Menurut Kongor, et al. (2013) potensi flavor kakao dapat diketahui dari kualitas fermentasi melalui indeks warna yang disebut indeks fermentasi.

\section{Biji Slaty}

Hasil pengamatan jumlah biji slaty menunjukkan berat biji perkotak dan waktu pengadukan berpengaruh sangat nyata terhadap jumlah biji 
slaty sedangkan interaksinya tidak berpengaruh nyata. Rata-rata jumlah biji slaty diperlihatkan pada Tabel 3 .

Tabel 3. Jumlah biji slaty

\begin{tabular}{ccccc}
\hline \multirow{2}{*}{ Pengadukan } & \multicolumn{3}{c}{ Berat biji per kotak } & \multirow{2}{*}{ Rataan } \\
\cline { 2 - 4 } & $\mathbf{1 5}$ & $\mathbf{2 0}$ & $\mathbf{2 5}$ & \\
\hline 1 kali & 3,6 & 1,6 & 2,4 & $2,5 \mathrm{a}$ \\
3 kali & 3,8 & 3,6 & 2,7 & $3,4 \mathrm{~b}$ \\
\hline Rataan & $3,7 \mathrm{~b}$ & $2,6 \mathrm{a}$ & $2,5 \mathrm{a}$ \\
\hline Keterangan: & Angka & yang diikuti huruf & yang berbeda $(\mathrm{a}, \mathrm{b})$ \\
& \multicolumn{4}{c}{ berarti berbeda nyata pada uji BNT 0,05}
\end{tabular}

Pada Tabel 3 memperlihatkan bahwa pengadukan 1 kali (48 jam) menghasilkan biji slaty lebih rendah $(2,5 \%)$ dibandingkan pengadukan 3 kali $(3,4 \%)$, hal ini diduga bahwa pada saat dilakukan pengadukan dan pembalikan semua biji sudah terfermentasi dengan baik, sehingga biji kakao tersebut termasuk kategori mutu I-B. Menurut Standar Nasional Indonesia (SNI 2323-2008) jumlah biji slaty maksimal 3\% (mutu I-B), sedangkan pengadukan 3 kali jumlah biji slaty $3,4 \%$. Sedangkan berat biji kakao $20 \mathrm{~kg}$ dan $25 \mathrm{~kg}$ per kotak menghasilkan biji slaty masingmasing 2,6\% dan 2,5\%

Mutu kakao dapat ditentukan secara fisik, kimia dan organoleptik. Secara fisik, tingkat kesempurnaan fermentasi dapat dilihat dari hasil cut test (uji belah). Cut test dilakukan dengan carabiji kakao dibelah secara diagonal dan warna dapat diamati secara kasat mata. Secara kualitatif kesempurnaan proses fermentasi dapat dilihat dari perubahan warna keping biji kakao. Dengan uji belah dapat dilihat warna dominan keping biji, tanpa fermentasi berwarna ungu (violet) atau sering disebut biji slaty. Warna tersebut secara bertahap akan berubah menjadi coklat sejalan dengan perkembangan proses dan lama fermentasi. Cut test digunakan secara visual untuk membedakan kesempurnaan proses fermentasi dari berbagai sampel biji kakao dan sekaligus sebagai acuan penentuan mutu dan harga biji kakao.

Biji slaty artinya biji yang tidak terfermentasi pada kakao lindak yang memperlihatkan separuh atau lebih permukaan irisan keping biji berwarna keabu-abuan seperti sabak atau biru keabu-abuan dan bertekstur padat dan pejal seperti keju (SNI 2323-2008 dalam BSN, 2008).Biji slaty akan memberikan rasa astringent (sepat) dan bitter (rasa pahit) berlebihan dan aroma kakao yang rendah (Misnawi, 2008).

$$
\text { Biji-biji yang difermentasi }
$$
secara penuh (fully fermented) ditandai dengan adanya warna coklat gelap pada 80 persen pada kulit luar dan kotiledon dan adanya pori-pori kecil di dalam biji, sedangkan pada fermentasi sebagian (half fermented) biji coklat tua tetapi tidak ada poripori dan fermentasi yang gagal (bad fermented) biji berwarna ungu dan tidak ada pori-pori di dalam biji (SCCP, 2013; Wahyudi dkk., 2013).

Senyawa polifenol merupakan penentu warna keping biji. Keberadaan polifenol tidak hanya bertanggung jawab terhadap 
pembentukan rasa pahit dan sepat, tetapi juga menyebabkan karakteristik warna coklat dari biji kakao terfermentasi (Misnawi et al., 2002). Biji tidak terfermentasi (slaty), ditandai dengan keping biji berwarnakeabu-abuan, bertekstur pejal, memiliki rasa sangat pahit, serta bercita rasa coklat. Polifenol teroksidasi dengan bantuan enzim polifenol oksidase membentuk senyawa tanin. Sebagian senyawa fenol yang tidak teroksidasi mendifusi keluar keping biji lewat testa, dengan berkurangnya senyawa polifenol warna keping biji yang semula ungu berubah menjadi coklat. Diferensiasi warna ungu berlangsung secara bertahap dan berkorelasi dengan penurunan konsentrasi polifenol dan lamanya proses fermentasi (Schwan, 1998). Oleh karena itu perubahan warna keping biji dipakai sebagai salah satu tolok ukur untuk penghentian proses fermentasi. Perubahan warna biji kakao karena adanya kandungan antosicyanin yang menyebabkan warna berubah dari ungu muda ke ungu gelap (Camu et aI.,2008).

\section{SIMPULAN DAN SARAN}

Berdasarkan hasil penelitian yang diperoleh, maka dapat disimpulkan sebagai berikut:

1. Fermentasi biji kakao pada skala kecil masing-masing $15 \mathrm{~kg}, 20 \mathrm{~kg}$, dan $25 \mathrm{~kg}$ tidak berpengaruh terhadap perubahan suhu, $\mathrm{pH}$, total asam dan indeks fermentasi.

2. Perlakuan waktu pengadukan berpengaruh nyata terhadap $\mathrm{pH}$, indeks fermentasi dan jumlah biji slaty. Pengadukan sebanyak 3 kali yaitu 48 jam, 72 jam dan 96 jam lebih sbaik daripada pengadukan satu kali (48 jam) dalam hal $\mathrm{pH}$ $(5,6)$, dan indeks fermentasi 1,62 Perlu dilakukan penelitian dengan melihat pengaruh tinggi tumpukan biji dan ukuran kotak terhadap keberhasilan proses fermentasi skala kecil.

\section{UCAPAN TERIMA KASIH}

Penulis menyampaikan terima kasih kepada Kementrian Ristek dan Pendidikan Tinggi yang telah mendanai penelitian dalam skim Hibah Bersaing sehingga penelitian ini dapat terlaksana dengan baik.

\section{DAFTAR PUSTAKA}

Alamsyah, T.S. (1991). Peranan Fermentasi dalam Pengolahan Biji Kakao Kering.Suatu Tinjauan. Berita Perkebunan, Vol. 1, No. 2, 97-103.

Amalia, H. A. (2014). Sulsel Targetkan Peningkatan Produksi Kakao 300.000 Ton Di 2016. Retrieved Juli 12, 2016, from http://www.beritasatu.com/ek onomi/224100-sulseltargetkan-peningkatanproduksi-kakao-300000-tondi-016.html.

Ardhana, M.M. \& Fleet, G. H. (2003). The Microbial Ecology of Cocoa Bean Fermentation In Indonesia. International Journal of Food Microbiology, Vol. 86, No. 12, 87-99.

Badan Standarisasi Nasional. (2008). SNI 2323: 2008. Biji Kakao. ICS.67.140.30. 
Camu, N., Winter, T. D. Addo, S. K., Takrama, J. S., Bernart, H. \& Vuyst, L. D. (2008). Fermentation of Cocoa Beans: Influence of Microbial Activities and Polyphenol Concentrations On The Flavour of Chocolate. Journal of the Science of Food and Agriculture, Vol. 88, No. 13, 2288-2297.

Gourieva, K. B \& Tserevitinov, O. B. (1979). Method of Evaluating The Degree of Fermentation of Cocoa Bean. USSR Patent No: 646254.

Guehi, T. S., Dadie, A. T., Koffi, K. P. B., Dabonne S., Ban-Koffi, L., Kedjebo, K. D., \& Nemlin, G. J. (2010). Performance of Different Fermentation Methods And The Effect of Their Duration On The Quality of Raw Cocoa Beans. International Journal of Food Science and Technology, Vol. 45, No.12, 2508-2514.

Iflah, T. \& Towaha, J. (2015). Perbedaan tingkat kematangan buah dan lama femeraman terhadap kualitas biji kakao. Warta Penelitian dan Pengembangan Tanaman Industri, Vol. 21, No. 3, 1417.

Indarti, E., Widayat, H. P., \& Zuhri, N. (2011). Effect of Fermentation Container and Thickness of Bean Mass During Fermentation Process of Cocoa Bean (Theobroma cocoa L.). Proceedings: Annual International
Conference(pp. 64-69). Banda Aceh: Univesitas Syiah Kuala.

Isra, S. (2016). BLB 50 : Solusi Nyata Produksi Kakao Berkelanjutan. Retrieved April 17, 2017, from http://www.kompasiana.com/i sra/blb-50-solusi-nyataproduksi-kakaoberkelanjutan_56aefcef50f9fd ef1127c288.

Jinap, S., Siti-Mordingah, H., \& Norsiati, M. G. (1994). Formation of Methyl Pyrazine During Cocoa Beans Fermentation. Pertanika Journal of Tropical Agricultural Science, Vol. 17, No. 1, 27-32.

Kementerian Pertanian, (2012). Teknologi Pengolahan Biji Kakao Menuju SNI Biji Kakao 01-2323-2008. Kementerian Pertanian: Balai Pengkajian Teknologi Pertanian Yogyakarta Balai Besar Pengkajian dan Pengembangan Teknologi Pertanian Badan Penelitian dan Pengembangan Pertanian.

Kustyawati, M. E. \& Setyani, S. (2008). Pengaruh Penambahan Inokulum Campuran Terhadap Perubahan Kimia dan Mikrobiologi Selama Fermentasi Cokelat. Jurnal Teknologi Industri dan Hasil Pertanian, Vol. 13, No. 2, 7384.

Lopez, A. S. \& Passos, F. M. L. (1984). Factor Influencing Cacao Bean Acidity; 
Kajian Pengaruh Berat Biji Kakao 29

Fermentation, Drying and The Microflora. 9th Int. Cacao Res. Conf (pp.701-704). Togo.

Misnawi. (2005). Peranan Pengolahan Terhadap Pembentukan Citarasa Cokelat. Warta Pusat Penelitian Kopi dan Kakao Indonesia, 21, 136-144.

Misnawi. (2008). Physico-Chemical Changes During Cocoa Fermentation and Key Enzymes Involved. Review Penelitian Kopi dan Kakao, Vol. 24, No. 1, 47-64.

Misnawi, Jinap, S., Jamilah, B., \& Nazamid, S. (2003). Effects of Incubation and Polyphenol Oxidase Enrichment Ton Colour, FermentationIndex, Procyanidins and Astringency of Unfermented and Partly Fermented Cocoa Beans.International Journal of Food Science \& Technology, Vol. 38, No. 3, 285-295.

Misnawi, S. J., Jamilah, B.,\& Nazamid, S. (2002). Activations of Remaining key Enzymes in Dried Under Fermented Cocoa Beans and its Effect on Aroma Precursors Formation. Food Chemistry, Vol. 78, No. 4, 407- 417.

Pasau, C. (2013). Efektivitas Penggunaan Asam Asetat Pada Pemeraman Biji Kakao Segar Sebagai Analog Fermentasi. E-journal Agrotekbis, Vol. 1, No. 2, 113120.
Ramlah, S. \& Daud, D. (2009). Pengaruh Lama Fermentasi Terhadap Warna dan Citarasa Biji Kakao.Jurnal Industri Hasil Perkebunan, Vol. 4, No. 1, 24-30.

SCCP. (2013). Pasca Panen, Pengolahan Biji Kakao Dan Fermentasi. Swiss Foundation for Technical Cooperation.

Schwan, R. F. (1998). Cocoa Fermentations Conducted With A Defined Microbial Cocktail Inoculum. Applied and Environmental Microbiology, Vol. 64, No. 4, 1477-1483.

Setiavani, G. (2009). Pengolahan Biji Kakao. Retrieved Juli, 13, 2016, from https:/guesty.wordpress.com/ 2009/01/28/pengolahan-bijikakao.

Sinartani. (2016). Fermentasi Kakao Untuk Rajai Pasar Dunia. Retrieved Juli 12, 2016, from http://tabloidsinartani.com/con tent/read/fermentasi-kakaountuk-rajai-pasar-dunia/.

Sri-Mulato, Wahyudi, T., Atmawinata, O., \& Amin, S. (1995). Beberapa alternatif sarana pengolahan kakao rakyat. Prosiding Seminar Pengeringan Biji Kakao dengan Energi Surya. Pusat Penelitian Kopi dan Kakao Indonesia. Jember.

Sudarmadji, S., Bambang, H., \& Suhardi, (1997). Prosedur Analisa Bahan Makanan dan Pertanian (Edisi ketiga). 
30 Jurnal Pendidikan Matematika dan IPA Vol. 8 No. 2 Juli 2017: 18-30

Yogyakarta: Liberty bekerjasama dengan Pusat Antar Universitas Pangan dan Gizi UGM

Takrama, J. F., Aculey, P. C., Aneani, F. (2006). Fermentation of Cocoa With Placenta: A Scientific Study. Proceedings of 15th International Cocoa Research Conference (pp. 1373-1379), Costa Rica, volume II.

Wahyudi, T., Panggabean, T. R., \& Pujiyanto (editor). (2013). Kakao, Manajemen Agribisnis Dari Hulu Hingga Hilir. Jakarta: Penebar Swadaya.

Widianto, D., Pramita, A. D., \& Wedhastri, S. (2013). Perbaikan Proses Fermentasi Biji Kakao Kering Dengan Penambahan Tetes Tebu, Khamir, dan Bakteri Asam Asetat. Jurnal Teknosains, Vol. 3, No. 1, 38-44.
Widyotomo, S. \& Sri-Mulato. (2008).

Teknologi Fermentasi dan

Diversifikasi Pulpa Kakao Menjadi Produk Yang Bermutu dan Bernilai Tambah. Review Penelitian Kopi dan Kakao, Vol. 24, No.1, 65-82.

Wood, G. A. R. \& Lass, R. A. (2001). Cocoa. 4th ed. Longman. London: Wiley-Blackwell. 